\title{
Optimization of Ni-YSZ Solid Oxide Fuel Cell anodes by surface laser melting
}

\author{
A. Cubero, J. I. Peña and M. A. Laguna-Bercero \\ Instituto de Ciencia de Materiales de Aragón (ICMA), CSIC- Universidad de Zaragoza \\ C/ Pedro Cerbuna 12, E-50009, Zaragoza, Spain \\ malaguna@unizar.es
}

A cermet composed of a metallic component (nickel) and a ceramic matrix (yttria stabilized zirconia) is commonly used as the anode for Solid Oxide Fuel Cells (SOFC). In the present work we intend to improve the performance of Ni-YSZ anodes by surface laser melting. Symmetrical cells, consisting of two NiO-YSZ anodes ( 20 $\mu \mathrm{m}$ thickness) separated by a relatively thin YSZ electrolyte $(\sim 500 \mu \mathrm{m})$ were fabricated by convectional ceramic techniques. Subsequently, laser melting treatments of both anodes were performed using a $\mathrm{CO}_{2}$ laser system, producing a NiO-YSZ eutectic lamellar microstructure. Laser power of $100 \mathrm{~W}$ and processing rates of $1 \mathrm{~mm} \mathrm{~s}^{-1}$ were determined as the optimum processing conditions. Symmetrical processed plates (eutectic sample) were electrically characterized by impedance spectroscopy (EIS), and the results were compared with non-processed plates (ceramic sample). Preliminary EIS results showed that the polarization resistance at higher temperatures (in the range of $900{ }^{\circ} \mathrm{C}$ ) is about $0.5 \Omega \mathrm{cm}^{2}$ for both the eutectic and the ceramic sample. However, at lower temperatures (in the range of $800^{\circ} \mathrm{C}$ ) the polarization resistance for both samples differs considerably $\left(2.9\right.$ and $1.6 \Omega \mathrm{cm}^{2}$ for the ceramic and eutectic sample, respectively). These experiments confirmed that optimization of the microstructure by laser surface treatment plays a crucial role in the electrochemical properties of the anode cermets.

Keywords: NiO, Yttria stabilized zirconia, eutectic, Solid Oxide Fuel Cells, laser processing 



\section{Introduction}

The typical material used as solid oxide fuel cell (SOFC) fuel electrode for both fuel cell and electrolysis applications is a cermet composed by an ionic conductor phase (YSZ: yttria stabilized zirconia) and a metallic phase (nickel). ${ }^{1,2}$ However, the current state of the art material presents some disadvantages including poor redox stability, low tolerance to sulphur, nickel coarsening after long-term operation and carbon deposition when using hydrocarbon fuels. ${ }^{3}$ The current problems could be avoided by either using alternative materials ${ }^{4}$ or by improving the present $\mathrm{Ni}$-YSZ materials. For example, a composite $\mathrm{Cu}-\mathrm{CeO}_{2}-\mathrm{YSZ} / \mathrm{SDC}$ anode demonstrated that the addition of $\mathrm{CeO}_{2}$ to $\mathrm{Cu}-\mathrm{YSZ} / \mathrm{SDC}$ cermet significantly enhanced the performance of the cell, especially for hydrocarbon fuels. ${ }^{5}$ However, one problem associated when using hydro-carbon fuels is that most of those fuels contain sulphur compounds as minor products, which are easily converted to hydrogen sulfide $\left(\mathrm{H}_{2} \mathrm{~S}\right)$ upon reforming, and thus deactivating the Ni-YSZ cermet. ${ }^{6}$ Another problem associated with Ni-YSZ anodes is the accidental reoxidation of $\mathrm{Ni}$ to $\mathrm{NiO}$, producing a microstructural irreversibility during the redox process and leading to strain accumulation, over several redox cycles. ${ }^{7}$ In order to solve this problem, infiltration of Ni metallic particles into porous YSZ have been proposed as a possible solution. ${ }^{8,9}$ Finally, last problem of Ni-YSZ cermets is related to $\mathrm{Ni}$ agglomeration during cell operation. This process is accelerated by the poor wettability between metallic Ni and the ceramic YSZ phase. ${ }^{10}$ It has been reported significant microstructural changes in the anode Ni phase over a range of operational times, including phase size growth and changes in connectivity,

interfacial contact area and contiguous triple-phase boundary (TPB) length. ${ }^{11} \mathrm{~A}$ possible solution is the use of channelled $\mathrm{Ni}-\mathrm{YSZ}$ anodes produced from NiO-YSZ 
directionally solidified eutectics (DSE). ${ }^{12}$ The low-energy interfaces formed between the phases ensure good stability of the material over time. It was reported that the channelled microstructure of this cermet improves the performance of the anode, allowing good gas flow and electronic conduction through the $\mathrm{Ni}$ porous lamellae. ${ }^{13}, 14,15$ However, although the advantages of the cermet material were demonstrated, the fabrication of a SOFC single cell containing a channelled cermet is still a challenge for practical applications, as a dense electrolyte needs to be deposited on top of a fully dense material. Garcia et al. showed that it is possible to fabricate dense YSZ films (from 5 to $10 \mu \mathrm{m}$ thick) by PI-MOCVD (pulsed injection metal organic chemical vapour deposition) on NiO-CaSZ (calcia stabilized zirconia) eutectics. ${ }^{16}$ In a similar approach, Merino et al. ${ }^{17}$ proved that applying surface laser melting to YSZ rich hypereutectic of YSZ-NiO ceramics, it is feasible to obtain layered material consisting of different layers: primary zirconia, eutectic with graded composition and single $\mathrm{NiO}$ phase. Once more, the fabrication of a SOFC cell by this procedure is still challenging. The objective of the present work is the fabrication of an electrolyte supported SOFC where the Ni-YSZ electrodes are produced from DSE using laser assisted techniques. Laser processing was previously used for SOFC applications including fabrication of $\mathrm{Ni}$, Co and Mn-YSZ eutectics, ${ }^{15,1819}$ drilling of Ni-YSZ supports, ${ }^{20}$ laser machining of selfsupporting YSZ electrolytes ${ }^{21}$ or micro- solid oxide fuel cells fabricated by pulsed laser deposition (PLD) techniques. ${ }^{22}$ In this work, Ni-YSZ/YSZ/Ni-YSZ symmetrical cells will be fabricated by conventional ceramic methods. Subsequently, laser melting treatments of both sides will be performed using a $\mathrm{CO}_{2}$ laser system, producing a NiO-YSZ eutectic lamellar microstructure. Symmetrical processed samples (eutectic) will be 
characterized by impedance spectroscopy, and the results will be compared with nonprocessed samples (conventional ceramic cermets).

\section{Materials and methods}

\subsection{Sample fabrication}

\subsubsection{Fabrication of the electrolyte supports}

YSZ ceramic substrates were fabricated by uniaxial pressing of YSZ powders ( 8 mol\% yttria stabilized zirconia, TZ-8Y, Tosoh, Japan) with a mean particle size of $0.2 \mu \mathrm{m}$, using poly-vinyl alcohol (PVA) as a binder, at $5 \mathrm{MPa}$. Green substrates were subsequently sintered at $1400{ }^{\circ} \mathrm{C}$ during 2 hours, achieving relative densities between $96 \%$ and $99 \%$. Final dimensions of the substrates after sintering are approximately: 20 $\times 8 \times 0.5$ (in $\mathrm{mm}$ ).

\subsubsection{Symmetrical cells fabrication}

NiO-YSZ suspensions were fabricated using 8YSZ (8 mol\% yttria stabilized zirconia, TZ8YS, Tosoh, Japan) with a mean particle size of $0.5 \mu \mathrm{m}$, and NiO (Alfa Aesar GmbH \&Co. KG, Germany) with a mean particle size of less than $44 \mu \mathrm{m}$. NiO powders were previously milled in an attrition mill for 2 hours using 2-propanol as solvent, in order to obtain a mean particle size of $1.2 \mu \mathrm{m}$. Particle size of the powders was determined using Dynamic Light Scattering (DSL) (Malvern Instruments Ltd, United Kingdom). Cornstarch was also used as a pore former, as porosity will help to dissipate heat and reduce thermal shock during laser treatments. Powders were finally mixed in ethanol media, using PVB (polyvinyl butyral) as binder and Beycostat as dispersant agent. In 
order to optimize slurry compositions, rheological measurements were performed using a rotational rheometer equipped with the Rheowin software (Haake Mars, Thermo Scientific, Germany). The measurements were performed operating in control rate (CR) mode at $20{ }^{\circ} \mathrm{C}$, and the conditions were from 0 to $1000 \mathrm{~s}^{-1}$ in 150 seconds, maintaining at this rate for 30 seconds and coming back to $0 \mathrm{~s}^{-1}$ at the same rate. Finally, YSZ ceramic substrates were dip-coated into the NiO-YSZ slurries. Four dipcoatings, drying at ambient air for 30 minutes between each dip, were needed to obtaining the desired anode thicknesses. Samples were finally sintered at $1350{ }^{\circ} \mathrm{C}$ for 2 hours, obtaining typical NiO-YSZ thicknesses in the range of $20 \mu \mathrm{m}$.

\subsubsection{Laser assisted directional solidification}

Laser surface melting was performed using a commercial pulsed $\mathrm{CO}_{2}$ laser (Marcatex Flexi 250, $10.6 \mu \mathrm{m}$ wavelength). Samples were placed on a metallic support inside of a furnace at temperatures in the range of $1000{ }^{\circ} \mathrm{C}$ in order to reduce the thermal shock during resolidification. The melting temperature of the NiO-YSZ eutectic $\left(\sim 1850{ }^{\circ} \mathrm{C}\right)$

was directly measured using a MINOLTA Land Cyclops 52 optical pyrometer. ${ }^{15} \mathrm{~A}$ homogeneous intensity laser line (10x1 $\mathrm{mm}$ size) was focussed on the surface of the sample, travelling at speeds varying from 1 to $10 \mathrm{~mm} / \mathrm{s}$ along the $Y$ direction. The treatment time for each anode of a typical sample is less than 30 seconds. Laser powers from 75 to $160 \mathrm{~W}$ were used. Frequencies as high as $20 \mathrm{KHz}$ were used in order to resemble the pulsed laser to a continuous laser. ${ }^{23}$ All laser parameters were controlled using the Easy Mark 2009 software. Additional details about laser surface melting of similar samples can be found in 17, 24.

\subsection{Microstructural and electrical characterization}


Microstructural analysis was performed using a field emission scanning electron microscope (FE-SEM) from Carl Zeiss, Germany (Merlin FE-SEM). Electrical characterization of the symmetrical cells was performed by electrochemical impedance spectroscopy (EIS) analysis. Samples were mounted in a spring-loaded test rig, designed and built in-house, using Pt mesh as current collectors. NiO paste (in-situ reduced to metallic $\mathrm{Ni}$ ) was applied to both sides of the pellets to improve current collection. The typical surface area of the anodes is $0.8 \mathrm{~cm}^{2}$. AC impedance measurements were recorded using a using a VSP impedance analyser (Princeton Applied Research, Oak Ridge, USA) in the frequency range of $10^{5} \mathrm{~Hz}$ to $0.1 \mathrm{~Hz}$ using an electrical perturbation of $20 \mathrm{mV}$. The data obtained was finally analysed using the ZPlot/Z-View software package (Scribner Associates, Southern Pines, NC, USA).

\section{Results and discussion}

\subsection{Symmetrical cells fabrication}

NiO-YSZ suspensions were firstly optimized. The selected composition of the precursor ceramics are (mol\%): $75 \mathrm{NiO}-25 \mathrm{YSZ}$ (5 mol\% extra of $\mathrm{NiO}$ is needed to compensate $\mathrm{NiO}$ evaporation during the melting process). ${ }^{1525}$ As discussed in the experimental section, $15 \%$ of corn-starch (in vol\%) was introduced as pore former to reduce thermal stress. Based on previous studies for $\mathrm{NiO}-\mathrm{YSZ}^{26}$ and $\mathrm{LSM}^{2} \mathrm{YSZ}^{27}$ similar compositions, we have fabricated suspensions of $10 \%$ of solid load in ethanol media using $5 \%$ of binder (PVB) and $1 \%$ of dispersant (Beycostat). The measured viscosity of the suspensions was $0.03 \mathrm{~Pa} \mathrm{~s}^{-1}$. After this, YSZ ceramic substrates were dip-coated into the NiO-YSZ slurries, obtaining typical NiO-YSZ thicknesses after sintering in the range of $15-20 \mu \mathrm{m}$, as observed in figure 1 . 


\subsection{Laser processing}

The parameters used for the laser surface melting of the samples are summarized in table 1. Two key parameters need to be controlled: the traverse speed $(V)$ of the sample and the power of the $\mathrm{CO}_{2}$ laser system. By increasing the speed of the sample, the solidification rate will be increased and as a consequence the interlamellar spacing $(\lambda)$ of the eutectic microstructure will be reduced. ${ }^{12}$ The relationship between $\lambda$ and $V$ according with the Hunt-Jackson law is described in equation (1). ${ }^{28}$

$$
\lambda V^{2}=\text { Constant }
$$

Considering the experimental interlamellar spacing founded by Dhalenne et $a .^{29}$ and Merino et al. ${ }^{14}$ for the NiO-CaSZ (calcia stabilized with zirconia) system, this constant is about $129 \mu \mathrm{m} 2 \mathrm{~mm} \mathrm{~h}^{-1}$. According with this value, an interlamellar spacing in the range of $200 \mathrm{~nm}$ is expected for processing rates of $\sim 1 \mathrm{~mm} \mathrm{~s}^{-1}$. The laser power is the additional parameter to be controlled, as it is necessary to completely melt the NiOYSZ coating without damaging the YSZ substrate. As observed from table 1, best conditions were found for traverse speed of $1 \mathrm{~mm} \mathrm{~s}^{-1}$ and laser power of $100 \mathrm{~W}$ (samples 1.4, 2.1 and 2). Typical microstructures for the different samples are shown in figure 2. Sample 1.1 showed partial sintering of the anode coating due to insufficient laser power $(75 \mathrm{~W})$ for that traverse speed $\left(1 \mathrm{~mm} \mathrm{~s}^{-1}\right)$. By increasing laser power by a factor of 2 using the same rate (sample 1.2, $150 \mathrm{~W}$ ) the total NiO-YSZ coating was

melted. However, the microstructure showed NiO-YSZ eutectic regions and segregation of primary phase of YSZ, especially near the YSZ support. Due to the higher laser power, nickel oxide was evaporated in excess during the melting process, and YSZ primary phase was segregated to compensate the evaporation. Finally, optimum 
conditions were founded for intermediate laser powers (100 W: sample 2.1), mainly showing the NiO-YSZ eutectic as observed in figure 2 . In order to get a finer microstructure, several attempts were also performed at $2 \mathrm{~mm} \mathrm{~s}^{-1}$. As observed for sample 2.3, $100 \mathrm{~W}$ was insufficient to melt all the NiO-YSZ coating. By increasing the laser power to $135 \mathrm{~W}$ (sample 2.4, microstructure shown in figure 2), all the coating was melted and the microstructure showed eutectic microstructure and segregation of both $\mathrm{NiO}$ and YSZ. If we compare this microstructure with sample 1.2, in this case as the traverse speed was increased by a factor of 2 , possibly there was not enough time for $\mathrm{NiO}$ evaporation and it segregated as primary phase. In general, during the experiments listed in table 1 we observed more superficial cracks in samples processed at higher rates. For that reason the processing parameters for $2 \mathrm{~mm} \mathrm{~s}^{-1}$ were not further optimized and the subsequent study will be performed with samples processed at $1 \mathrm{~mm} \mathrm{~s}^{-1}$. As observed from figure 2, image analysis for sample 2.1 showed an interlamellar spacing $(\lambda)$ of ca. $286 \mathrm{~nm}$, and the thickness of each phase was ca. $90 \mathrm{~nm}$ and $200 \mathrm{~nm}$ for the YSZ and $\mathrm{NiO}$, respectively.

After optimization of the laser processing parameters, NiO-YSZ/YSZ/NiO-YSZ symmetrical cells were laser processed on both sides. From now on, the processed sample will be referred as eutectic sample. Non-processed samples (will be referred as ceramic samples) were also fabricated for comparison. All symmetrical cells were then firstly reduced at $800{ }^{\circ} \mathrm{C}$ under humidified hydrogen atmosphere. Typical microstructures for both ceramic and eutectic samples after reduction are shown in figure 3. It is expected that the channelled microstructure of this cermet will improve the performance of the anode, allowing good gas flow and electronic conduction through the Ni porous lamellae. In addition, as previously reported for Ni-YSZ samples 
produced from reduction of NiO-YSZ eutectic compositions, aging experiments under a continuous flow of dry $\mathrm{H}_{2} / \mathrm{N}_{2}$ for $300 \mathrm{~h}$ at $900{ }^{\circ} \mathrm{C}$ showed that the low-energy interfaces formed between YSZ and NiO phases ensure good stability of the material over time. ${ }^{13}$ Nickel connectivity within the cermet was also analysed. In fact, SEM images shown in figure 3 are collected using an InLens secondary electron detector, using acceleration voltages in the range of $1 \mathrm{kV}$. By this analysis it is possible to distinguish between percolating and non-percolating nickel. ${ }^{30}$ This is clearly observed from figure 3 that the eutectic sample presents much better connectivity between nickel metalling particles, due to the finer and well-aligned microstructure.

\subsection{Electrical characterization}

Finally, both ceramic and eutectic samples were preliminarily characterized by EIS measurements. Note that the thickness of the functional electrodes of the symmetrical thickness is between 8 to $15 \mu \mathrm{m}$. This is a non-optimized parameter, as the electrochemical active area of a Ni-YSZ anode could be up to $30 \mu \mathrm{m} .{ }^{31}$ Typical Nyquist plots are shown in figure 4. For clarification purposes, ohmic contributions were subtracted and the polarization resistances were divided by two in order to account each electrode. According with literature data, ${ }^{32}$ the impedance response of the hydrogen/water reaction on Ni-YSZ cermet electrodes at OCV (open circuit voltage) involves up to three processes with different dependencies on temperature and the partial pressure of the reactants. At temperatures below $845^{\circ} \mathrm{C}$, the impedance was found to be charge-transfer controlled. The capacitances of this contribution appear in the range of $\sim 10^{-4} \mathrm{~F} \mathrm{~cm}^{-2}$, and this parameter is very dependent to the microstructure. 
At temperatures above $890^{\circ} \mathrm{C}$, two reaction steps, charge transfer and adsorption due to a high fractional surface coverage, determine the overall reaction rate. Similar findings were reported by Primdahl et al. ${ }^{33}$ They reported that the high frequency (HF) contribution is the only one microstructure dependent and it is attributed to a combination of resistance of charge-transfer from Ni to YSZ and oxide ions resistance in YSZ particles in the cermet. In addition, based in the literature, activation energies for $\mathrm{Ni}-\mathrm{YSZ}$ electrodes ranged from 0.7 to $1.8 \mathrm{eV}$ depending on the geometry, sintering temperature and raw materials employed. ${ }^{34}$

In our experiments (fig. 4), Ni-YSZ polarization resistance is thermally activated and decreases with temperature, as expected. In addition, polarization resistances for both the eutectic and ceramic samples are rather similar at the high temperature range (900-950 ㄷ). However, significant differences are observed when decreasing the operation temperature, where the polarization resistance decreases for the eutectic sample. As observed in figure 4 , the experimental data was fitted using two R-CPE components, as shown in the inset of the figure. R1 component is appearing at high frequencies (HF) and R2 at low frequencies (LF). In concordance with previous studies reported in the literature, R1-HF component was attributed to the microstructure of the cermet and R2-LF component was attributed to surface adsorption. At temperatures below $850{ }^{\circ} \mathrm{C}$, the microstructure of the anodes (charge-transfer controlled, R1-HF) plays a crucial role in the polarization resistance. Due to the well aligned and dispersed microstructure of the eutectic sample, R1-HF component significantly decreases at lower temperatures. All the analysed parameters are summarized in table 2. As observed, R2-LF component is about constant for both samples, whereas R1-HF component decreases considerably for the eutectic sample. 
The activation energy for the ceramic sample $(1.86 \mathrm{eV})$ is slightly higher than those reported in the literature possibly due to the small thickness of the functional electrode $(\sim 10 \mu \mathrm{m})$. Although the thickness of the eutectic sample is in the same range, the activation energy is significantly reduced $(1.31 \mathrm{eV})$ as a consequence of the well aligned microstructure. As observed from table 2, the polarization resistance is reduced by approximately a factor of two at temperatures close to $800{ }^{\circ} \mathrm{C}$.

\section{Conclusions}

Optimization of laser processing parameters was performed in order to fabricate NiOYSZ/YSZ/NiO-YSZ symmetrical cells, where the NiO-YSZ layers ( 20 $\mu \mathrm{m}$ thickness) possess an eutectic lamellar microstructure. Optimum laser conditions were founded for laser powers of about $100 \mathrm{~W}$ and processing rates of $1 \mathrm{~mm} \mathrm{~s}^{-1}$. Symmetrical nonprocessed samples were also fabricated for comparison purposes. Polarization resistance at higher temperatures (in the range of $900{ }^{\circ} \mathrm{C}$ ) was found to be similar for both samples (about $\left.0.5 \Omega \mathrm{cm}^{2}\right)$. However, at lower temperatures $\left(\sim 800{ }^{\circ} \mathrm{C}\right.$ ) the polarization resistance of the eutectic sample is significantly smaller $\left(1.6 \Omega \mathrm{cm}^{2}\right)$ than the ceramic sample $\left(2.9 \Omega \mathrm{cm}^{2}\right)$ due to the well-aligned microstructure for the eutectic sample. Although these experiments need to be confirmed by optimized cells with thicker electrodes, it is demonstrated that optimization of the microstructure is essential to improve the electrochemical properties of electrodes, and thus reducing the operation temperature of SOFC devices.

\section{Acknowledgements}


Authors would like to thank grant MAT2012-30763, financed by the Spanish Government (Ministerio de Economía y Competitividad) and Feder program of the European Community. Prof. V. M. Orera is also acknowledged for helpful discussions. The use of Servicio de Microscopia Electronica (University of Zaragoza) is finally acknowledged. 
Table 1. Summary of the laser processed samples.

\begin{tabular}{|c|c|c|c|}
\hline $\begin{array}{l}\text { Sample } \\
\text { code }\end{array}$ & $\begin{array}{l}\text { Traverse speed } \\
\quad\left(\mathrm{mm} \mathrm{s}^{-1}\right)\end{array}$ & $\begin{array}{l}\text { Laser power } \\
\text { (W) }\end{array}$ & Results \\
\hline 1.1 & 1 & 75 & Sintering of the layer (no melting) \\
\hline 1.2 & 1 & 150 & $\begin{array}{l}\text { Total melting. Some cracks } \\
\text { YSZ primary phases + eutectic zones }\end{array}$ \\
\hline 1.3 & 10 & 100 & Sintering of the layer (no melting) \\
\hline 1.4 & 1 & 100 & $\begin{array}{l}\text { Total melting. No cracks } \\
\text { Majority of eutectic microstructure }\end{array}$ \\
\hline 2.1 & 1 & 100 & $\begin{array}{c}\text { Total melting. No cracks } \\
\text { Majority of eutectic microstructure }\end{array}$ \\
\hline 2.2 & 1 & 100 & $\begin{array}{l}\text { Total melting. No cracks } \\
\text { Majority of eutectic microstructure }\end{array}$ \\
\hline 2.3 & 2 & 100 & Partial melting \\
\hline 2.4 & 2 & 135 & $\begin{array}{c}\text { Total melting. Severe cracks } \\
\mathrm{NiO} \text { and YSZ primary phases + eutectic zones }\end{array}$ \\
\hline 2.5 & 2 & 145 & $\begin{array}{c}\text { Total melting. Severe cracks } \\
\mathrm{NiO} \text { and YSZ primary phases + eutectic zones }\end{array}$ \\
\hline 2.6 & 2 & 160 & $\begin{array}{l}\text { Total melting. Severe cracks } \\
\mathrm{NiO} \text { and YSZ primary phases }+ \text { eutectic zones }\end{array}$ \\
\hline
\end{tabular}

Table 2. Resistances obtained by fitting the experimental EIS data for the eutectic and ceramic samples at the studied temperatures.

\begin{tabular}{|c|c|c|c|c|c|c|c|c|c|}
\hline Sample & $\begin{array}{c}\text { Temp. } \\
\left({ }^{\circ} \mathrm{C}\right)\end{array}$ & $\begin{array}{c}\mathrm{R} 1 \\
\left(\Omega \mathrm{cm}^{2}\right)\end{array}$ & $\begin{array}{c}\mathbf{R 2} \\
\left(\Omega \mathrm{cm}^{2}\right)\end{array}$ & $\begin{array}{c}\text { ASR } \\
\left(\Omega \mathrm{cm}^{2}\right)\end{array}$ & Sample & $\begin{array}{c}\text { Temp. } \\
\left({ }^{\circ} \mathrm{C}\right)\end{array}$ & $\begin{array}{c}\mathrm{R} 1 \\
\left(\Omega \mathrm{cm}^{2}\right)\end{array}$ & $\begin{array}{c}\mathbf{R 2} \\
\left(\Omega \mathrm{cm}^{2}\right)\end{array}$ & $\begin{array}{c}\text { ASR } \\
\left(\Omega \mathrm{cm}^{2}\right)\end{array}$ \\
\hline \multirow{7}{*}{ Ceramic } & 815 & 2.49 & 0,41 & 2.90 & \multirow{7}{*}{ Eutectic } & 810 & 1.19 & 0.42 & 1.61 \\
\hline & 840 & 1.72 & 0.24 & 1.96 & & 840 & 1.07 & 0.29 & 1.36 \\
\hline & 875 & 1.06 & 0.12 & 1.18 & & 870 & 0.84 & 0.20 & 1.04 \\
\hline & 906 & 0.68 & 0.08 & 0.76 & & 901 & 0.58 & 0.16 & 0.74 \\
\hline & 925 & 0.51 & 0.07 & 0.58 & & 917 & 0.43 & 0.15 & 0.58 \\
\hline & 943 & 0.43 & 0.06 & 0.49 & & 937 & 0.33 & 0.13 & 0.46 \\
\hline & \multicolumn{3}{|c|}{$E_{\mathrm{a}}(\mathrm{eV})$} & 1.86 & & \multicolumn{3}{|c|}{$E_{\mathrm{a}}(\mathrm{eV})$} & 1.31 \\
\hline
\end{tabular}


Figure 1. SEM image (transverse cross-section) showing a porous NiO-YSZ anode deposited on top of a YSZ electrolyte. Arrows indicate the additional porosity caused by the pore former.

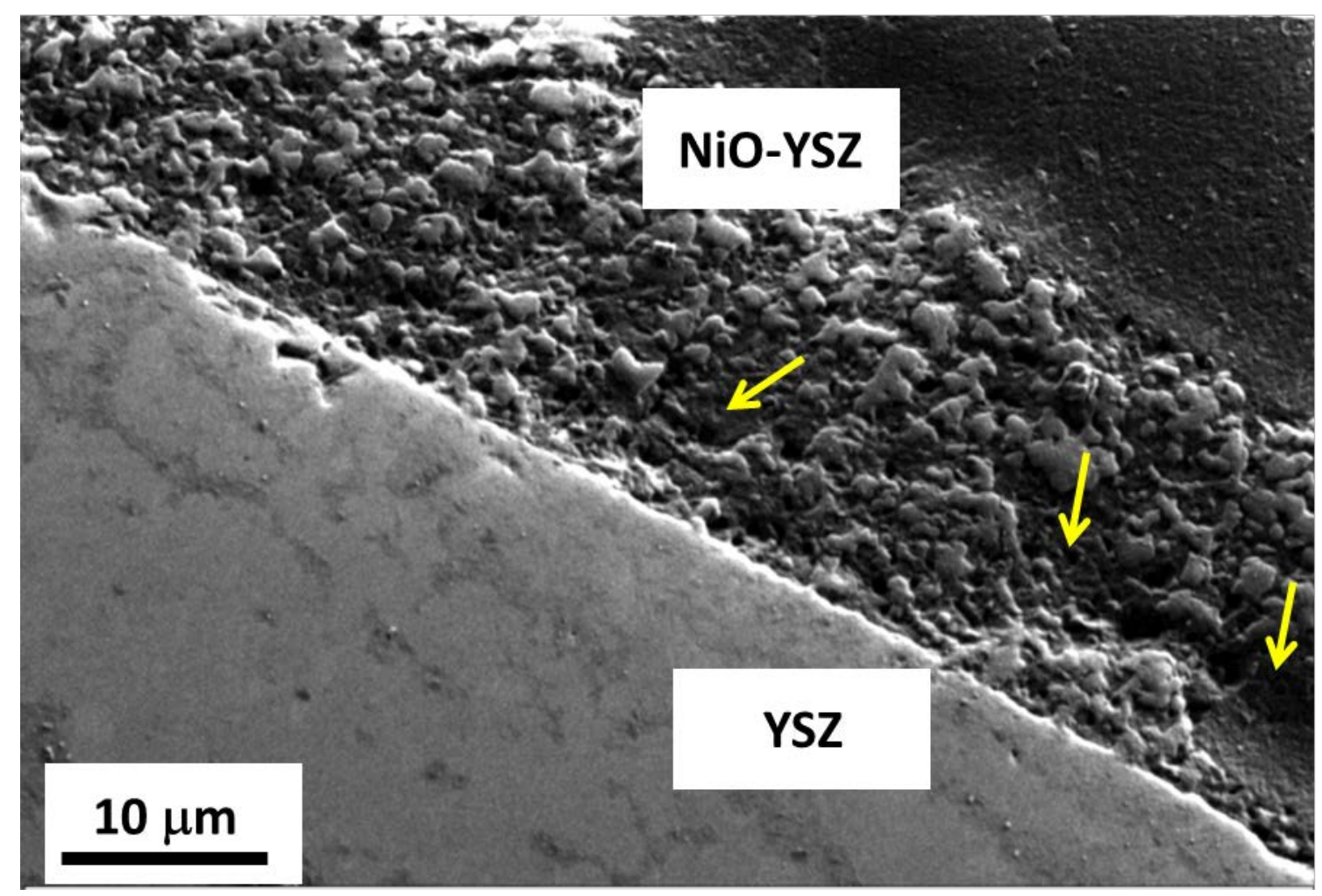


Figure 2. SEM images (transverse cross- sections) of different surface laser treatments.

Brightness scale: YSZ (dark phase) and NiO (light phase).
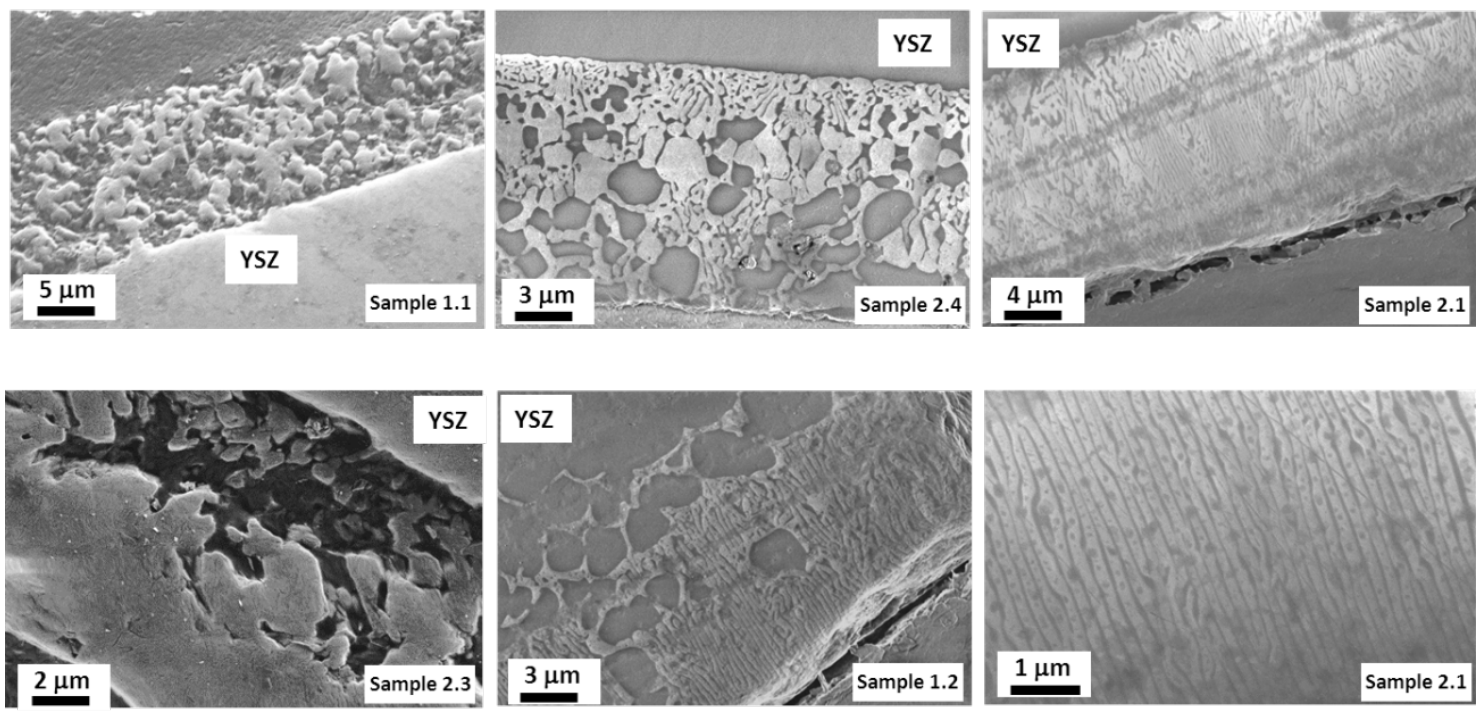
Figure 3. SEM images (transverse cross- sections) for the ceramic (left) and eutectic (right) samples after reduction. Brightness scale: YSZ (dark phase) and NiO (light phase).
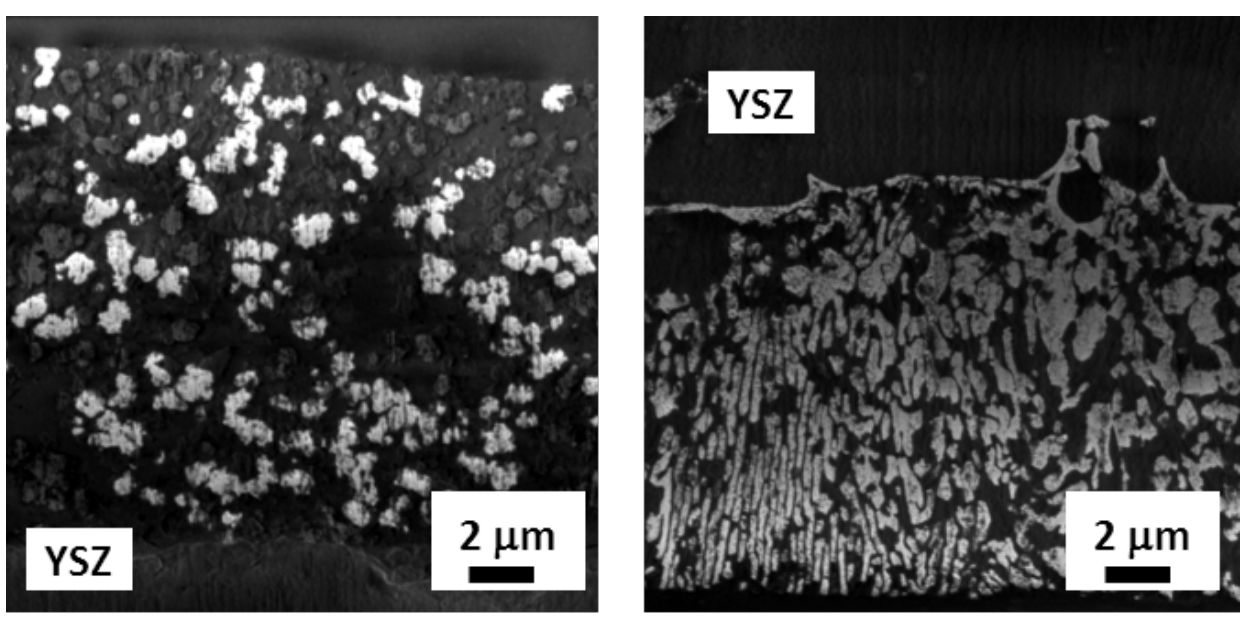
Figure 4. EIS impedance analysis for the eutectic and ceramic sample at 810 and 815 oC, respectively. The equivalent circuit shown in the inset was used to fit (solid line) the experimental data (open circles and squares).

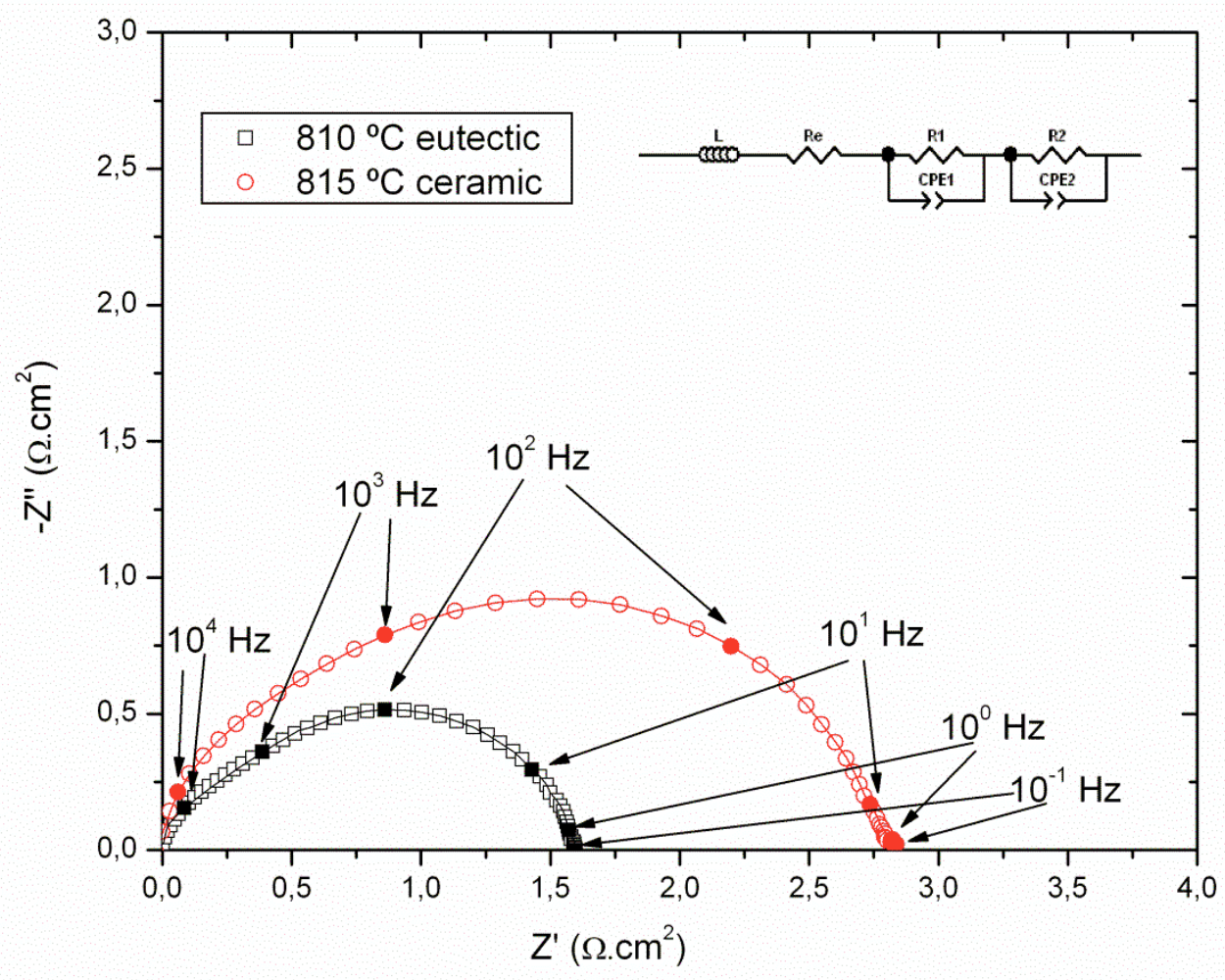




\section{References}

1 S.C. Singhal, K. Kendall (Eds.), High Temperature SOFCs: Fundamentals, Design and Applications, Elsevier, 2003.

${ }^{2}$ M. A. Laguna-Bercero, J. Power Sources 203, 1-16 (2012).

${ }^{3}$ Chunwen Sun, Ulrich Stimming, Recent anode advances in solid oxide fuel cells, J. Power Sourc. 2007, $171,2,247-260$.

4John B. Goodenough, Yun-Hui Huang, Alternative anode materials for solid oxide fuel cells, J. Power Sourc. 2007, 173, 1, 1-10.

${ }^{5}$ S. Park, J.M. Vohs, R.J. Gorte, Nature, 404 (2000), pp. 265-267

${ }^{6}$ Zhe Cheng, Jeng-Han Wang, Yong Man Choi, Lei Yang, M. C. Lin and Meilin Liu, Energy Environ. Sci., 2011,4, 4380-4409

7 Sarantaridis, D., Atkinson, A., Redox cycling of Ni-based solid oxide fuel cell anodes: A review (2007) Fuel Cells 7 (3) $246-258$

${ }^{8}$ Busawon, A.N., Sarantaridis, D., Atkinson, A., Ni infiltration as a possible solution to the redox problem of SOFC anodes (2008) Electrochemical and Solid-State Letters 11 (10) PP. B186 - B189

${ }^{9}$ Hanifi, A.R., Torabi, A., Chen, X., Hill, S., Sarkar, P., Etsell, T.H., Development of redox resistant fully infiltrated tubular SOFCs (2014) Journal of the Electrochemical Society 161 (4) PP. F391 - F397

${ }^{10}$ A. Tsoga, A. Naomidis and, and P. Nikolopoulos, "Wettability and Interfacial Reactions in the Systems $\mathrm{Ni}$ /YSZ and Ni/Ti-TiO2/YSZ," Acta Mater., 44, 3679-92 (1996).

${ }^{11}$ Nelson, G.J., Grew, K.N., Izzo Jr., J.R., Lombardo, J.J., Harris, W.M., Faes, A., Hessler-Wyser, A., Van Herle, J., Wang, S., Chu, Y.S., Virkar, A.V., Chiu, W.K.S., Three-dimensional microstructural changes in the $\mathrm{Ni}$-YSZ solid oxide fuel cell anode during operation (2012) Acta Materialia 60 (8) PP. 3491 - 3500

12 Javier Llorca, Victor M. Orera, Directionally solidified eutectic ceramic oxides, Progress in Materials Science 51 (2006) 711-809

${ }^{13}$ Miguel A. Laguna-Bercero, Angel Larrea, Rosa I. Merino, Jose I. Peña, and Victor M. Orera, Stability of Channeled Ni-YSZ Cermets Produced from Self-Assembled NiO-YSZ Directionally Solidified Eutectics, J. Am. Ceram. Soc., 88 [11] 3215-3217 (2005).

${ }^{14}$ R. I. Merino, J. I. Peña, M. A. Laguna-Bercero, A. Larrea, and V. M. Orera, “Directionally Solidified Calcia Stabilised Zirconia-Nickel Oxide Plates in Anode Supported Solid Oxide Fuel Cells," J. Eur. Ceram. Soc., 24, 1349-53 (2004).

${ }^{15}$ M. A. Laguna-Bercero, A. Larrea, R. I. Merino, J. I. Peña, and V. M. Orera, "Structured Porous Ni- and Co-YSZ Solidified Eutectic Composites," J. Eur. Ceram. Soc., 25, 1455-62 (2005).

${ }^{16}$ G. Garcia, R. I. Merino, V. M. Orera, A. Larrea, J. I. Peña, M. A. Laguna-Bercero, J. A. Pardo, J. Santiso, and A. Figueras, "YSZ Thin Films Deposited on NiO-CSZ Anodes by Pulsed Injection MOCVD for Intermediate Temperature SOFC Applications," Chem. Vap. Deposition, 10, 249-52 (2004).

${ }^{17}$ Rosa I. Merino, J.I. Peña, V.M. Orera, Compositionally graded YSZ-NiO composites by surface laser melting. J.Eur. Ceram. Soc. 30, 2, 2010, 147-152.

${ }^{18}$ M. A. Laguna-Bercero, A Larrea, RI Merino, JI Peña, VM Orera, J.Eur. Ceram. Soc. 28 (12), 2325-2329

${ }^{19}$ A. Orera, J.I. Peña, S. Serrano-Zabaleta, A. Larrea, V.M. Orera, Fibrillar Mn304-YMnSz well-ordered eutectics with potential functional applications, J. Eur. Ceram. Soc. 35 (2015) 909-918.

${ }^{20}$ Gurauskis, J., Sola, D., Peña, J.I., Orera, V.M., Laser drilling of Ni-YSZ cermets, J. Eur. Ceram. Soc. 28 (2008) 2673-2680.

${ }^{21}$ A. Larrea, D. Sola, M. A. Laguna-Bercero, J. I. Peña, R. I. Merino, and V. M. Orera, Self-Supporting Thin Yttria-Stabilised Zirconia Electrolytes for Solid Oxide Fuel Cells Prepared by Laser Machining, J.

Electrochem. Soc. 158 (2011) B1193-B1197.

22 Muecke, U.P., Beckel, D., Bernard, A., Bieberle-Hütter, A., Graf, S., Infortuna, A., Müller, P., Rupp, J.L.M., Schneider, J., Gauckler, L.J., Micro solid oxide fuel cells on glass ceramic substrates, Adv. Funct. Mater. 18 (2008) 3158-3168.

${ }^{23}$ W. M. Steen, Laser Material Processing, Springer-Verlag, London (2003).

${ }^{24}$ Larrea, A., de la Fuente, G. F., Merino, R. I. and Orera, V. M., ZrO2-Al2O3 eutectic plates produced by laser zone melting. J. Eur. Ceram. Soc., 2002, 22, 191-198. 
${ }^{25}$ MA Laguna-Bercero, A Larrea, YSZ-Induced Crystallographic Reorientation of Ni Particles in Ni-YSZ Cermets, J.Am. Ceram. Soc. 90 (2007), 2954-2960

${ }^{26}$ J. F. Beltran-Lopez, M. A. Laguna-Bercero, J. Gurauskis, J. I. Peña, Fabrication and Characterization of Graded Anodes for Anode-Supported Solid Oxide Fuel Cells by Tape Casting and Lamination. Electrocatalysis 5 (2014) 273-278.

${ }^{27}$ MA Laguna-Bercero, R Campana, A Larrea, JA Kilner, VM Orera, Steam electrolysis using a microtubular solid oxide fuel cell, J.Electrochem.I Soc. 157 (2010), B852-B855.

${ }^{28}$ W. A. Tiller, "Polyphase solidification", in: Liquid metals and solidification. Am. Soc. Metals, Cleveland, 1958, 276-318.

${ }^{29} \mathrm{G}$. Dhalenne, A. Revcolevschi, Directional solidification in the NiO-ZrO2 system, J. Cryst. Growth 69 (1984) 616-618.

${ }^{30} \mathrm{~K}$. Thydén, Y.L. Liu, J.B. Bilde-Sørensen, Microstructural characterization of SOFC Ni-YSZ anode composites by low-voltage scanning electron microscopy, Solid State lon. 178 (2008) 1984-1989.

${ }^{31} \mathrm{~K}$. Miyawaki, M. Kishimoto, H. Iwai, M. Saito, H. Yoshida, Comprehensive understanding of the active thickness in solid oxide fuel cell anodes using experimental, numerical and semi-analytical approach, J. Power Sourc. 267 (2014) 503-514.

32 P. Holtappels, I. C. Vinke, L. G. J. de Haart, U. Stimming, J. Electrochem. Soc. 146 (1999) 2976.

${ }^{33}$ S. Primdahl, M. Mogensen, J. Electrochem. Soc. 144 (1997), 3409.

${ }^{34}$ M. Mogensen, K. V. Jensen, M. J. Jørgensen, S. Primdahl, Solid State Ion. 150 (2002) 123-129 